\title{
The different tests for the diagnosis of COVID-19 - A review in Bra- zil so far
}

\author{
Ana Flávia Santarine Laureano술 ${ }^{1}$ árcia Riboldi² \\ ${ }^{1}$ Universidade Federal do ABC, Centro de Ciências Naturais e Humanas, São Bernardo do Campo - SP \\ ${ }^{2}$ Igenomix, São Paulo - SP
}

\begin{abstract}
SARS-CoV-2 is a novel virus from the coronavirus family that emerged in the end of December 2019 in Wuhan, China. The virus is now widespread and causing the current pandemic of COVID-19, a highly pathogenic viral pneumonia, commonly presented with fever and cough, which frequently lead to lower respiratory tract disease with poor clinical outcomes associated with older age and underlying health conditions. Supportive care for patients is typically the standard protocol because no specific effective antiviral therapies have been identified so far. The current outbreak is challenging governments and health authorities all over the world. In here we present a comparison among the current diagnostic tools and kits being used to test Brazilian population.
\end{abstract}

Keywords: Immunochromatography, ELISA, PCR, diagnostic tool, COVID-19

\section{Background}

The coronavirus disease 2019 (COVID-19) epidemic started in December 2019, in Wuhan, Hubei province, in China. It rapidly spread across China and other countries, raising major global concerns (Tang et al., 2020). Its etiological agent is the SARS-CoV-2 (Wu et al., 2020) also referred to as HCoV-19 (Jiang et al., 2020). According to the latest update by the World Health Organization (WHO, 2020a) up to April 28, 2020 there were 2,959,929 confirmed cases with 202,733 deaths in 213 countries, areas or territories so far.

The current COVID-19 outbreak is both similar and different to the prior SARS (2002-2003) and MERS (2012-ongoing) outbreaks. SARS was initiated by zoonotic transmission of a novel coronavirus (likely from bats via palm civets) in markets in Guangdong province, China. MERS was also traced to zoonotic transmission of a novel coronavirus (likely from bats via dromedary camels) in Saudi Arabia. All three viral infections commonly presented with fever and cough, which frequently lead to lower respiratory tract disease with poor clinical outcomes associated with older age and underlying health conditions (Wu \& McGoogan, 2020).

The treatment of COVID-19 is supportive. To date, no vaccine, antiviral or other specific treatment is available, however, there are several studies in progress (Wu \& McGoogan, 2020). Also, it is not known whether infectiousness starts before onset of symptoms. The incubation period for COVID-19 is about 5-6 days ( Li et al., 2020a). Combining this time with a similar length serial interval suggests there might be considerable presymptomatic infectiousness (Anderson et al., 2020). So far there have been few clinical studies to measure COVID-19 viremia and how it changes over time in individuals (Anderson et al., 2020). In one study of 17 patients diagnosed with COVID-19, peak viremia seems to be at the end of the incubation period (Zou et al., 2020), pointing to the possibility that viremia might be high enough to trigger transmission for 1-2 days before onset of symptoms.

Diagnostic tests for COVID-19 have stood out in the current coronavirus pandemic as an essential tool for tracking the spread of the disease. The genetic sequence of the 2019 novel coronavirus enabled the rapid development of diagnostics tests specific for SARS-CoV-2 (Wang et al., 2020). Since there is a wide range of diagnostic tests commercially available for SARSCoV-2, in this review we present a comparison among of all them and the techniques used to test Brazilian population.

Figure 1. COVID-19 cases in Brazil. Number of cases per state (A) and per region (B) Data collected from State Health Secretaries. Adapted from Brazil, 2020.

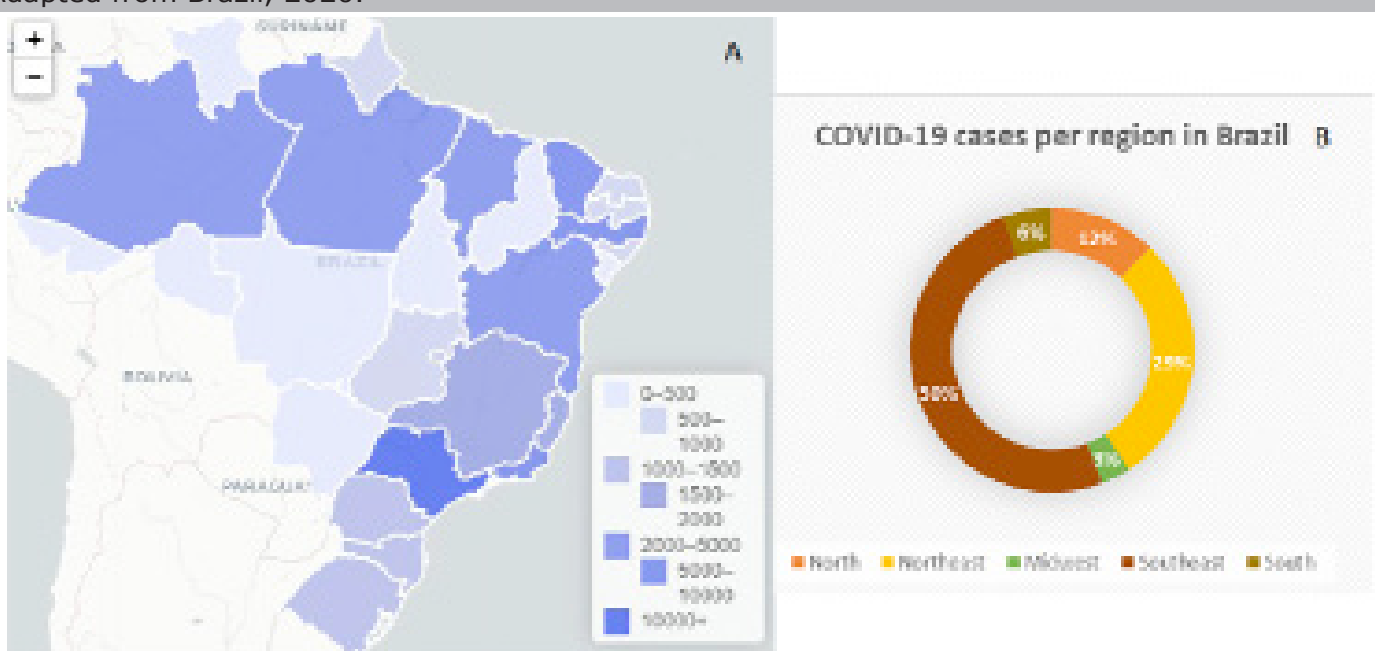




\section{The Brazilian perspective and diagnostic tests available}

In Brazil, the first case of COVID-19 was confirmed on February 26, 2020 by the Ministry of Health. A 61-yearold man was admitted to a private hospital with a history of travel to Italy, but he was already at home when he presented the symptoms. Since then, on April 25, 2020, 58,509 cases have been confirmed, most of them in the state of São Paulo. Figure 1 illustrates the number of cases per state in Brazil.

Brazilian Health Regulatory Agency (Anvisa) published the Resolution (RDC 348/2020), which established extraordinary and temporary rules to speed up the evaluation of new products by prioritizing the analysis of test registration requests for detection of the new coronavirus (SARSCoV-2). The idea is not to evaluate and approve products automatically, as sanitary rigor must always exist, but rather to speed up the process. The measure is part of the strategic actions to enable products that can be used to face the COVID-19 pandemic. Anvisa's role is to promote the protection of the population's health by executing sanitary control of the production, marketing and use of products and services subject to health regulation, including related environments, processes, ingredients and technologies, as well as the control in ports, airports and borders. On March 19, the Brazilian Health Regulatory Agency approved the first eight rapid tests for the diagnosis of COVID-19. At the date of the review, 39 tests have been approved by Anvisa so far. Of the 39 approved, 21 are rapid tests. There are tests that use blood, serum or plasma and others that need samples of secretions collected from the airways, such as nasopharynx (nose) and oropharynx (throat). Table 1 and 2 summarizes all kits and tests registered in Brazil. Data regarding accuracy have been extracted from manual instructions available at Anvisa website.

\section{Rapid Test or Point of care testing (POCT)}

Most rapid tests use colloidal gold particles in a technique known as immunochromatography, also called lateral flow immunoassay, a type of sandwich assay that relies on a pair of antibodies used to recognize two independent epitopes of a protein, and therefore it can achieve high specificity (Zhou et al., 2012).

Lateral flow assays only require the application of a sample (sometimes followed by the application of a buffer solution) and can yield a result within 5-15 minutes (O'Farrell, 2009). This kind of test is being used for pregnancy (Puertas et al., 2010), HIV (Granade et al., 2010), bacterial infections (Huang, 2007), drugs of abuse (Gonzalez et al., 2011), food contaminants (No et al., 2007) and dengue virus (Cuzzubbo et al., 2001), and many tests are commercially available (Zhou et al., 2012). Lateral flow assays are also being developed for global health applications, where devices that are inexpensive and easy-to-use are required. However, lateral flow assays are generally not quantitative and often only give a yes/no answer (Zhou et al., 2012).

A typical immunochromatographic strip is composed by a sample-loading pad (O'Farrell, 2009), a glass fibre pad with detection antibody ( $\mathrm{dAb}$ ) conjugated to gold nanoparticles (AuNPs) or latex beads (Xu et al., 2007), a nitrocellulose or polyvinylidene fluoride membrane with pre-immobilized capture antibody ( $C A b)$, a control antibody for test validation (Puertas et al., 2010) and an absorbent pad used as capillary pump to draw the sample solution (O'Farrell, 2009).

To perform a lateral flow, assay the sample containing the target analyte (antigen) is loaded on the sample pad and flows through the membrane by capillary effects. The liquid first dissolves the dAb-AuNP conjugates and the antigen binds to the $d A b$. As the antigen-dAb pair flows through the capture zone, the cAb will capture the labelled antigen. Further downstream, the unbound dAb-AuNP reacts with the control antibody, which binds specifically to $\mathrm{dAb}$ irrespective of the antigen. Both the capture and control lines may become visible due to the accumulation of the AuNPs that produce collective plasmonic effects and result in a red colour (Xu et al., 2007). The colour on the control line indicates the test is valid, and the colour on the capture line suggests the presence of target analyte in the sample solution (Zhou et al., 2012).

For COVID-19 the tests have been developed with AuNPs conjugated with recombinant-anti-COVID-19 antigens. The sample (whole blood, serum or plasma) is added to the pad and, the antibodies against COVID-19 present in the sample, interact with the AuNPs and run through the membrane. When in contact with the test regions these gold-antibodies conjugated are immobilized and a colour line appears on the strip. The presence of the line indicates a positive result. The absence indicates a negative result. There is also a control line, as an indicative that the test is valid. Independent on the result the test is only valid if the control line appears. Figure 2 is an example of how this technology works.

In this context many companies and research groups developed rapid lateral flow immunoassay tests for testing specific antibodies of SARS-CoV-2 in patient blood for being a rapid, simple, highly sensitive diagnosis (Li et al., 2020b).

One of the first rapid tests (lateral flow immunoassay) for SARS-CoV-2 IgG and IgM immune responses was developed by professor's Feng Ye group at the National Clinical Research Centre for Respiratory Disease in Guangzhou, China. The clinical efficiency of the tests was validated by collecting blood samples from 397 PCR confirmed COVID-19 patients and 128 negative patients at 8 different clinical sites. The overall testing sensitivity was $88.66 \%$ and specificity was $90.63 \%$ (Li et al., 2020b). This

Figure 2. Example of a lateral flow immunochromatographic assay strip (Adapted from O'Farrell, 2009).

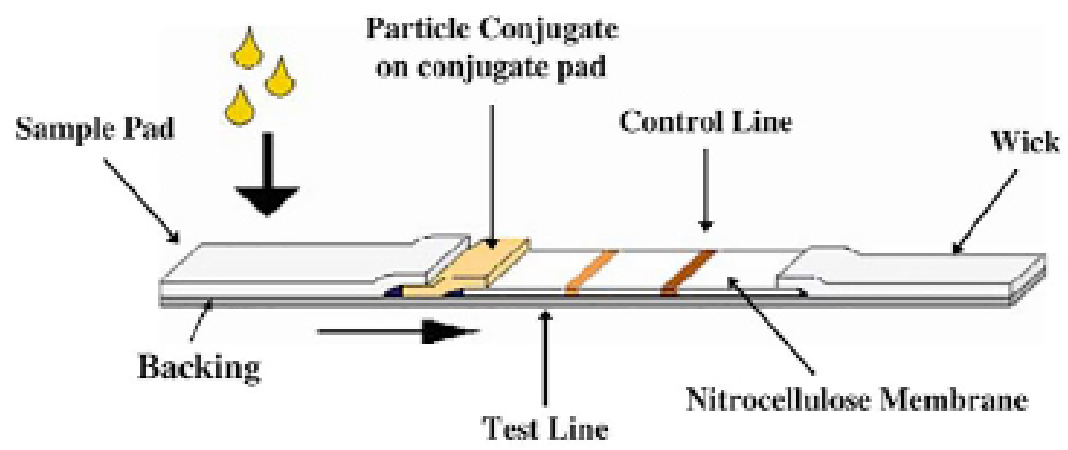


combined test is being designed and manufactured by Jiangsu Medomics Medical Technologies (Nanjing, China).

From the 39 tests approved 21 are immunochromatographic tests to evaluate the presence of IgG and IgM antibodies against SARS-CoV-2. Sample material for those tests are whole blood, serum or plasma and the time for yielding a result varies from 10-20 minutes. Specificity to IgM antibodies was $94-98 \%$ according to the manufacturer while for the IgG was $97-98 \%$. The sensibility for the IgM antibodies was $85-90 \%$ and for IgG $95-100 \%$. Three tests - One Step COVID-2019 Test (Celer Biotecnologia S/A), CORONAVIRUS RAPID TEST (Biocon Diagnósicos) and DPP $\AA$ COVID-19 IgM/IgG System (Orangelife) had no available data regarding sensibility and specificity for IgG and IgM.

The manufacturers of the tests CORONAVÍRUS IgG/ IgM (COVID-19) and 2019-nCoV IgG/IgM Teste Rápido em Cassete reported that hematocrit levels may affect results. The hematocrit level should be between $25 \%-65 \%$ to yield accurate results. The manufacturer of MedTeste Coronavírus (COVID-19) IgG/IgM informed that results of immunocompromised patients should be interpreted with caution. The manufacturer of the test Anti COVID-19 IgG/ IgM Rapid Test declared that no false results were observed in positive sample for the pathogens: influenza $A$, influenza BRSV, adenovirus, HBsAg syphilis, Helicobacter pylori, HIV and HCV.

In general, this kind of assay shows some advantages such as: it is an established mature technology; relative ease of manufacture since equipment and processes are already developed and available; easily scalable to high volume production, stable, since shelf-lives varies from 12 to 24 months often without refrigeration; ease of use; relatively low cost and short timeline for development and approval (O'Farrell, 2009). However, we have found relatively little current information reporting the diagnostic performance of these POC devices using clinical samples taken from community settings. Relevant data may still be under collection in ongoing studies or may not be published publically.

\section{ELISA}

The enzyme immunoassays (EIA) and enzyme-linked immunosorbent assays (ELISA) are both widely used as diagnostic tools for the detection and quantification of specific antigens or antibodies in a given sample (Gan \& Patel, 2013). Both techniques share similar basic principles and are derived from the radioimmunoassay (RIA). RIA was first described by Berson and Yalow, for which Yalow was awarded the Nobel Prize in 1977, to measure endogenous plasma insulin (Yalow \& Berson, 1996). RIA was then developed into a novel technique to detect and measure biological molecules present in exceedingly small quantities, paving the way for more analysis and detection of countless other biological molecules, including hormones, peptides and proteins. Because of the safety concerns regarding its use of radioactivity, RIA assays were modified by replacing the radioisotope with an enzyme, thus creating the modern-day EIA and ELISA (Gan \& Patel, 2013).

Both assays use the basic immunology concept of an antigen binding to its specific antibody, which allows detection of small quantities of antigens such as proteins, peptides, hormones or even antibodies in a fluid sample. Those assays utilize enzyme-labelled antigens and antibodies to detect biological molecules; the most used enzymes being alkaline phosphatase (EC 3.1.3.1) and glucose oxidase (E.C. 1.1.3.4). The antigen in fluid phase is immobilized, usually in a 96-well microtiter plate. The antigen can bind to a specific antibody, which is itself subsequently detected by a secondary, enzyme-coupled antibody. A chromogenic substrate for the enzyme yields a visible colour change or fluorescence, indicating then the presence of the antigen. Quantitative or qualitative measures can be assessed based on such colorimetric reading. (Gan \& Patel, 2013).

Although ELISA methodology could help track antigen exposure, it has some limitations: the enzyme-mediated colour change will react indefinitely. Over a sufficient long period of time, the colour strength will inaccurately reflect the amount of primary antibody present, yielding false-positive results; to detect a given antibody or antigen, a known reciprocal antigen or antibody must be generated and, nonspecific binding of the antibody or antigen to the plate will lead to a falsely high-positive result (Gan \& Patel, 2013).

\section{Polymerase Chain Reaction}

In acute respiratory infection, RT-PCR is routinely used to detect causative viruses from respiratory secretions. PCR is an enzyme-driven process for replicating DNA in vitro. PCR can produce enough amounts of DNA so that pathogens can be detected and identified. Because each pathogen has a unique complement of DNA or RNA, those molecules can function as a molecular fingerprint to help identify what is the organism causing one disease. In this technique a segment of DNA is copied in vitro by using a thermostable DNA polymerase enzyme in the presence of buffer, magnesium, deoxyribonucleoside triphosphates and primers. Oligonucleotide primers complementary to regions on the coding and the noncoding strand of the DNA template are responsible for specificity in the reaction, determining which region of the DNA becomes amplified. As the primers anneal to their complementary regions of DNA, DNA polymerases attach to the primer-template complexes and extend the DNA strands, producing a copy of the DNA. Each copy may then serve as another template for further amplification. Multiple rounds of heating and cooling of the reaction mixture in a thermal cycler produce rounds of melting of the double-stranded DNA, annealing of primer to single-stranded templates, and extension of DNA strands, to produce a logarithmic increase in DNA. In the ideal scenario, the primers chosen in the PCR are specific for a pathogen gene, and hence do not amplify nonspecific targets such as human genes. Theoretically, one could start with a single copy of the target pathogen gene present in the reaction and generate billions of copies of DNA from that gene (Fredricks \& Relman, 1999).

There are several approaches for using PCR to detect pathogen DNA, the simplest one being specific PCR where the primers are designed to attach to complementary regions of a DNA target (specific to the pathogen that is being assayed). Broad-range PCR attempt to detect a broader group of organisms by designing primers that are complementary to conserved regions of a particular gene that are shared by a given taxonomic group (Relman, 1998). Another variation is multiplexing, in which multiple specific PCR assays are run simultaneously in the same reaction tube test for multiple different DNA templates. In multiplex PCR several sets of primers are added to the reaction in order to generate several different PCR products. In this case postamplification methods are needed to determine which organism is represented in a positive reaction (Fredricks \& Relman, 1999).

PCR is possibly the most quintessential molecular method yet developed. Real-time quantitative PCR (qPCR) revolutionized clinical application of PCR partly because it automated analysis by removing the need for postreaction manipulation (Huggett et al., 2015). qPCR is over 20 year old (Higuchi et al., 1992), but it has only really been applied clinically in areas which alternatives are not practically possible, such as monitoring treatment in diseases like chronic-phase chronic myeloid leukaemia (Cross et al., 2012) or for some key blood borne viruses (Fryer et al., 2008). 
Table 1. All tests authorized by ANVISA to be used in diagnosing COVID-19 in Brazil so far (NA no available information at $20 / 04 / 2020$ )

\begin{tabular}{|c|c|c|c|}
\hline Test name & Register number & Process & Manufacturer \\
\hline One-Step COVID-2019 test & 80537410048 & $25351.174464 / 2020-54$ & Celer Biotecnologia S/A \\
\hline Coronavirus Rapid Test & 80638720148 & $25351.167156 / 2020-72$ & Diagnóstica Indústria e Comércio LTDA - ME \\
\hline Coronavirus IgG/IgM (COVID-19) & 10159820239 & $25351.153719 / 2020-45$ & Ebram Produtos Laboratoriais Ltda. \\
\hline Medteste Coronavirus 2019-nCov IgG/IgM & 80560310056 & $25351.189196 / 2020-75$ & $\begin{array}{l}\text { MedLevensohn Comércio e Representações } \\
\text { Hospitalares Ltda. }\end{array}$ \\
\hline $\begin{array}{l}\text { Teste rápido em Cassete 2019-nCoV IgG/IgM } \\
\text { (blood / serum / plasma) }\end{array}$ & 81325990117 & $25351.189190 / 2020-06$ & $\begin{array}{l}\text { QR Consulting Importação e Distribuição de } \\
\text { Produtos Médicos Ltda. }\end{array}$ \\
\hline COVID-19 IgG/IgM ECO Test & 80954880132 & $5351.148977 / 2020-18$ & Eco Diagnóstica Ltda. \\
\hline ECO F COVID-19 Ag & 80954880131 & $25351.162809 / 2020-27$ & Eco Diagnóstica Ltda. \\
\hline COVID-19 Ag ECO Teste & 80954880133 & $25351.112132 / 2020-86$ & Eco Diagnóstica Ltda. \\
\hline Anti COVID-19 IgG/IgM Rapid Test & 10009010356 & $25351.191493 / 2020-81$ & Labtest Diagnóstica S/A \\
\hline $\begin{array}{l}\text { Detection Kit real time PCR VIASURE SARS- } \\
\text { CoV-2 }\end{array}$ & 10355870373 & $25351.193569 / 2020-11$ & CerTest Biotec S.L. \\
\hline cobas $^{\circledast}$ SARS-CoV-2 & 10287411491 & $25351.193402 / 2020-41$ & Roche, Diagnostica \\
\hline Lumiratek COVID-19 (IgG/IgM) & 81327670112 & $25351.197132 / 2020-48$ & Lumiradx Healthcare Ltda. \\
\hline Maglumi IgM de 2019-nCoV (CLIA) & 80102512431 & $25351.206083 / 2020-41$ & $\begin{array}{l}\text { VR Medical Importadora e Distribuidora de } \\
\text { produtos Médicos Ltda. }\end{array}$ \\
\hline Maglumi IgG de 2019-nCoV (CLIA) & 80102512430 & 25351.206115/2020-17 & $\begin{array}{l}\text { VR Medical Importadora e Distribuidora de } \\
\text { produtos Médicos Ltda. }\end{array}$ \\
\hline Smart Test Covid-19 Vyttra & 81692610175 & $25351.200980 / 2020-41$ & Vyttra Diagnósticos Importação e Exportação \\
\hline
\end{tabular}

Table 2. Performance of diagnostic tests approved by ANVISA in Brazil for COVID-19. (*data extracted from technical instructions from the diagnostic kits available in the register area ate ANVISA website; NA: not available; CI confidence interval).

\begin{tabular}{|c|c|c|c|c|}
\hline Test Name & Accuracy data* & Methodology & Sample & $\begin{array}{l}\text { R e s u I t } \\
\text { time }\end{array}$ \\
\hline One Step COVID-2019 Test & $\begin{array}{l}\text { Sensibility: 86,43\% (CI 95\%: 82,41-89,58) } \\
\text { Specificity: 99,57\% (CI 95\%: 97,63 - 99,92\%) }\end{array}$ & $\begin{array}{l}\text { Immunochromatographic qualita- } \\
\text { tive assay for detection of both IgG } \\
\text { and IgM anti-coronavirus }\end{array}$ & $\begin{array}{l}\text { Whole blood, serum } \\
\text { or plasma }(10 \mu \mathrm{L})\end{array}$ & $15 \mathrm{~min}$ \\
\hline CORONAVÍRUS RAPID TEST & $\begin{array}{l}\text { Sensibility: 86,4\% (CI 95\%: 82,41\% - 89,58\%) } \\
\text { Specificity: 99,57\% (CI 95\%: 97,63\% - 99,92\%) }\end{array}$ & $\begin{array}{l}\text { Immunochromatographic qualita- } \\
\text { tive assay for detection of both IgG } \\
\text { and IgM anti-coronavirus }\end{array}$ & $\begin{array}{l}\text { Whole blood, serum } \\
\text { or plasma }(10 \mu \mathrm{L})\end{array}$ & $15 \mathrm{~min}$ \\
\hline $\begin{array}{l}\text { CORONAVÍRUS } \quad \text { IgG/lgM } \\
\text { (COVID-19) }\end{array}$ & $\begin{array}{l}\text { IgG } \\
\text { Sensibility: }>99,9 \% \\
\text { Specificity: } 98,0 \% \\
\text { Accuracy: } 98,6 \% \\
\text { IgM } \\
\text { Sensibility: } 85,0 \% \\
\text { Specificity: } 96,0 \% \\
\text { Accuracy: } 92,9 \%\end{array}$ & $\begin{array}{l}\text { Immunochromatographic qualita- } \\
\text { tive assay for detection of both IgG } \\
\text { and IgM anti-coronavirus }\end{array}$ & $\begin{array}{l}\text { Whole blood, serum } \\
\text { or plasma }(10 \mu \mathrm{L})\end{array}$ & $10-20 \mathrm{~min}$ \\
\hline 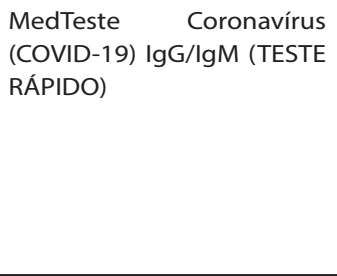 & $\begin{array}{l}\text { IgG } \\
\text { Sensibility: 97,4\% (CI 95\%: 86,2\% - 99,9\%) } \\
\text { Specificity: 99,3\% (CI 95\%: 96,2\% - 99,9\%) } \\
\text { Accuracy: 98,9\% (CI 95\%: 96,1\% - 99,9\%) } \\
\text { IgM } \\
\text { Sensibility: 86,8\% (CI 95\%: 71,9\% - 95,6\%) } \\
\text { Specificity: 98,6\% (CI 95\%: 95,0\% - 99,8\%) } \\
\text { Accuracy: 96,1\% (CI 95\%: } \mathbf{9 2 , 2 \% ~ - ~ 9 8 , 4 \% ) ~}\end{array}$ & $\begin{array}{l}\text { mmunochromatographic qualita- } \\
\text { tive assay for detection of both IgG } \\
\text { and IgM }\end{array}$ & $\begin{array}{l}\text { Whole blood, serum } \\
\text { or plasma }(10 \mu \mathrm{L})\end{array}$ & NA \\
\hline $\begin{array}{l}\text { Família Teste Rápido em } \\
\text { Cassete 2019-nCoV IgG/ } \\
\text { IgM (sangue total/soro/ } \\
\text { plasma) }\end{array}$ & $\begin{array}{l}\text { IgG } \\
\text { Sensibility: } 100 \% \text { (CI 95\%: } 86.0 \%-100 \% \text { ) } \\
\text { Specificity: } 98.0 \% \text { (CI 95\%: } 89.4 \%-99.9 \%) \\
\text { Accuracy: } 98.6 \% \text { (CI 95\%: } 92.3 \%-99.96 \% \text { ) } \\
\text { IgM } \\
\text { Sensibility: } 85.0 \% \text { (CI 95\%: 62.1\% - 96.8\%) } \\
\text { Specificity: } 96.0 \% \text { (CI 95\%: } 86.3 \%-99.5 \% \text { ) } \\
\text { Accuracy: } 92.9 \% \text { (CI 95\%: } 84.1 \%-97.6 \% \text { ) }\end{array}$ & $\begin{array}{l}\text { Immunochromatographic quali- } \\
\text { tative assay for detection of both } \\
\text { IgG and IgM against 2019-nCoV }\end{array}$ & $\begin{array}{l}\text { Whole blood, serum } \\
\text { or plasma }(10 \mu \mathrm{L})\end{array}$ & $10 \mathrm{~min}$ \\
\hline
\end{tabular}


Three tests use RT-PCR as the core technology to detect SARS-CoV-2 in samples of the airways of the patients, targeting the conserved genes ORF1ab and N. Probes with fluorescent reporter dye are used to make the detection. Positive results are indicative of the presence of RNA of the virus, but a clinical correlation with patient's history is necessary. Tests are highly sensitive. These data were provided by Secretaria de Ciência, Tecnologia, Inovação e Insumos Estratégicos em Saúde - SCTIE (2020).

\section{When should we use all the tests?}

On 2 March 2020, WHO released an interim guidance regarding laboratory testing for COVID-19 in suspected human cases recommending that tests should be based on clinical and epidemiological factor and linked to assessment of the likelihood of infection. But is also recommended PCR testing of asymptomatic or mildly symptomatic cases (WHO, 2020b). We should keep in mind that the gold standard for diagnosing COVID-19, as referred by WHO, are nucleic acid amplification tests (NAAT) such as RT-PCR, followed by nucleic acid sequencing when necessary. The viral genes targeted so far include the N, E, S and RdRP genes (WHO, 2020b).

Serological testing can aid investigation of an ongoing outbreak and retrospective assessment of the attack rate or extent of an outbreak. In cases were NAAT assays are negative and there is a strong epidemiological link to COVID-19 infection, paired serum samples (in the acute and convalescent phase) could support diagnosis once validated serology tests are available (WHO, 2020b).

It is widely accepted that IgM provides the first line of defence during viral infections, prior to the generation of adaptive, high affinity IgG responses, that are important for long term immunity and immunological memory (Racine \& Winslow, 2009). It was reported that after SARS infection, IgM antibody could be detected in patient blood after 3-6 days and IgG after 8 days (Lee et al., 2010). Since COVID-19 belongs to the same family of viruses as those that caused MERS and SARS outbreaks it is reasonable to infer that its antibody generation process is similar, and detection of the IgG and IgM antibody against SASRCoV-2 will be an indicator of infection ( $\mathrm{Li}$ et al., 2020b).

Cross reactivity to other coronaviruses can be challenging but commercial and non-commercial serological tests are currently under development (Meyer et al., 2014). Some studies with COVID-19 serological data on clinical samples have been published and could help in the development of future tests (Xiao et al., 2020).

\section{CONCLUSIONS}

COVID-19 is a novel disease caused by a novel coronavirus (SARS-CoV-2) that emerged in 2019 that is challenging scientists all over the world since its appearance. It is not, however, the first time that coronaviruses are responsible for outbreaks of major importance: SARS (China, 20022003) and MERS (Saudi Arabia, 2012-ongoing) were both caused by coronavirus. SARS had an overall case fatality rate (CFR) of $9.6 \%$ while MERS presents a CFR of $34.4 \%$. So far, COVID-19 presents a current CFR of $2.6 \%$, however, the total number of COVID-19 cases is likely higher due to inherent difficulties in identifying and counting mild and asymptomatic cases (Wu \& McGoogan, 2020) and, it is known that asymptomatic cases act as carriers of SARSCoV-2. However the mechanism by which asymptomatic carriers could acquire and transmit SARS-CoV-2 still requires further study (Bai et al., 2020).

The effort to contain the outbreak is limited by one hard problem: how to differentiate COVID-19 cases from the healthy. For confirmed COVID-19 cases reported the common clinical symptoms include fever, cough, myalgia or fatigue (Huang et al., 2020). Yet these symptoms are not unique features of COVID-19 because these symptoms are similar to that of other virus-infected diseases such as influenza (Wang et al., 2014).

It is clear the urgent need for rapid, simple to use, sensitive and accurate test to quickly identify infected patients to prevent virus transmission and to assure timely treatment of patients in order to contain this outbreak. We need to acknowledge that all three methodologies exposed here have its advantages and disadvantages and they can and should be combined to address this crisis to map the course of the disease and assure that is not spreading any further.

\section{CONFLICT OF INTEREST}

The author has no conflict of interest to declare.

\section{Corresponding Author:}

Ana Flávia Santarine Laureano

Universidade Federal do ABC

São Bernardo do Campo - SP

Email: laureano.ana@ufabc.edu.br

\section{REFERENCES}

Anderson RM, Heesterbeek $H$, Klinkenberg $D$, Hollingsworth TD. How will country-based mitigation measures influence the course of the COVID-19 epidemic? Lancet, 2020; 395: 931-4.

PMID: 32164834 DOI:10.1016/S0140-6736(20)30567-5

Bai Y, Yao L, Wei T, Tian F, Jin DY, Chen L, Wang M. Presumed Asymptomatic Carrier Transmission of COVID-19. JAMA. 2020; 323:1406-1407.

PMID:32083643 DOI:10.1001/jama.2020.2565

Brasil. Coronavirus Painel Coronavírus. 2020 Avaiable at: https://covid.saude.gov.br/ Accessed: 28/04/2020.

Cross NC, White HE, Müller MC, Saglio G, Hochhaus A. Standardized definitions of molecular response in chronic myeloid leukemia. Leukemia. 2012; 26:2172-5.

PMID:22504141 DOI:10.1038/leu.2012.104

Cuzzubbo AJ, Endy TP, Nisalak A, Kalayanarooj S, Vaughn DW, Ogata SA, Clements DE, Devine PL. Use of recombinant envelope proteins for serological diagnosis of dengue virus infection in an immunochromatographic assay. Clin Diagn Lab Immunol. 2001; 8:1150-5.

PMID:11687456 DOI:10.1128/CDLI.8.6.1150-1155.2001

Fredricks DN, Relman DA. Application of Polymerase Chain Reaction to the Diagnosis of Infectious Diseases. Clin Infect Dis. 1999; 29:475-86

PMID: 10530433 DOI: $10.1086 / 598618$

Fryer JF, Baylis SA, Gottlieb AL, Ferguson M, Vincini GA, Bevan VM, Carman WF, Minor PD. Development of working reference materials for clinical virology. J Clin Virol. 2008; 43:367-71

PMID:18823817 DOI:10.1016/j.jcv.2008.08.011

Gan SD, Patel KR. Enzyme immunoassay and enzyme-linked immunosorbent assay. J Invest Dermatol. 2013;133:e12

PMID:23949770 DOI:10.1038/jid.2013.287

Gonzalez JM, Foley MW, Bieber NM, Bourdelle PA, Niedbala RS. Development of an ultrasensitive immunochromatography test to detect nicotine metabolites in oral fluids. Anal Bioanal Chem. 2011;400:3655-64

PMID: 21556750 DOI:10.1007/s00216-011-5051-y 
Granade TC, Workman S, Wells SK, Holder AN, Owen SM, Pau CP. Rapid detection and differentiation of antibodies to HIV-1 and HIV-2 using multivalent antigens and magnetic immunochromatography testing. Clin Vaccine Immunol. 2010;17:1034-9

PMID: 20410326 DOI:10.1128/CVI.00029-10

Higuchi R, Dollinger G, Walsh PS, Griffith R. Simultaneous Amplification and Detection of Specific DNA Sequences. Biotechnology. 1992;10:413-7.

PMID: 1368485 DOI:10.1038/nbt0492-413

Huang C, Wang Y, Li X, Ren L, Zhao J, Hu Y, Zhang L, Fan G, Xu J, Gu X, Cheng Z, Yu T, Xia J, Wei Y, Wu W, Xie X, Yin W, Li H, Liu M, Xiao Y, et al. Clinical features of patients infected with 2019 novel coronavirus in Wuhan, China. Lancet. $2020 ; 395: 497-506$.

PMID: 31986264 DOI:10.1016/S0140-6736(20)30183-5

Huang SH. Gold nanoparticle-based immunochromatographic assay for the detection of Staphylococcus aureus. Sensors Actuat B-Che. 2007; 127:335-40.

DOI: https://doi.org/10.1016/j.snb.2007.04.027

Huggett JF, Cowen S, Foy CA. Considerations for digital $\mathrm{PCR}$ as an accurate molecular diagnostic tool. Clin Chem. 2015; 61:79-88

PMID:25338683 DOI:10.1373/clinchem.2014.221366

Jiang S, Shi Z, Shu Y, Song J, Gao GF, Tan W, Guo D. A distinct name is needed for the new coronavirus. Lancet. 2020;395:949.

PMID:32087125 DOI:10.1016/S0140-6736(20)30419-0

Lee HK, Lee BH, Seok SH, Baek MW, Lee HY, Kim DJ, Na YR, Noh KJ, Park SH, Kumar DN, Kariwa H, Nakauchi M, Heo SJ, Park JH. Production of specific antibodies against SARS-coronavirus nucleocapsid protein without cross reactivity with human coronaviruses $229 \mathrm{E}$ and OC43. J Vet Sci. 2010; $11: 165-7$.

PMID: 20458159 DOI: 10.4142/jvs.2010.11.2.165

Li Q, Guan X, Wu P, Wang X, Zhou L, Tong Y, Ren R, Leung KSM, Lau EHY, Wong JY, Xing X, Xiang N, Wu Y, Li C, Chen Q, Li D, Liu T, Zhao J, Liu M, Tu W, et al. Early Transmission Dynamics in Wuhan, China, of Novel Coronavirus-Infected Pneumonia. N Engl J Med. 2020a; 382:1199-207 PMID: 31995857 DOI: 10.1056/NEJMoa2001316

Li Z, Yi Y, Luo $X$, Xiong $N$, Liu $Y$, Li S, Sun R, Wang $Y$, Hu B, Chen W, Zhang Y, Wang J, Huang B, Lin Y, Yang J, Cai W, Wang X, Cheng J, Chen Z, Sun K, et al. Development and Clinical Application of A Rapid IgM-IgG Combined Antibody Test for SARS-CoV-2 Infection Diagnosis. J Med Virol. 2020b. PMID:32104917 DOI:10.1002/jmv.25727

Meyer B, Drosten C, Müller MA. Serological assays for emerging coronaviruses: Challenges and pitfalls. Virus Res. 2014;194:175-83

PMID: 24670324 DOI:10.1016/j.virusres.2014.03.018

No HY, Kim YA, Lee YT, Lee HS. Cholinesterase-based dipstick assay for the detection of organophosphate and carbamatepesticides. Anal Chim Acta. 2007;594:37-43 PMID: 17560383 DOI: 10.1016/j.aca.2007.05.008

O'Farrell B. Evolution in Lateral Flow-Based Immunoassay Systems. In: Wong RC, Tse HY, eds. Lateral Flow Immunoassay. New York, NY: Humana Press; 2009. p.133

DOI: $10.1007 / 978-1-59745-240-3 \_1$
Puertas S, Moros M, Fernández-Pacheco R, Ibarra MR, Grazú V, de la Fuente JM. Designing novel nano-immunoassays: Antibody orientation versus sensitivity. J Phys D Appl Phys. 2010; 43: 474012

DOI: $10.1088 / 0022-3727 / 43 / 47 / 474012$.

Racine $R$, Winslow GM. IgM in microbial infections: Taken for granted?'. Immunol Lett. 2009; 125:79-85 PMID: 19539648 DOI: 10.1016/j.imlet.2009.06.003

Relman DA. Detection and identification of previously unrecognized microbial pathogens. Emerg Infect Dis. 1998; 4:382-9.

PMID: 9716951 DOI: 10.3201/eid0403.980310

Tang X, Wu C, Li X, Song Y, Yao X, Wu X, Duan Y, Zhang H, Wang Y, Qian Z, Cui J, Lu J. On the origin and continuing evolution of SARS-CoV-2 Natl Sci Rev, 2020: nwaa036 https://doi.org/10.1093/nsr/nwaa036

Wang C, Yu H, Horby PW, Cao B, Wu P, Yang S, Gao H, Li H, Tsang TK, Liao Q, Gao Z, Ip DK, Jia H, Jiang $H$, Liu B, Ni MY, Dai X, Liu F, Van Kinh N, Liem NT, et al. Comparison of patients hospitalized with influenza a subtypes H7N9, H5N1, and 2009 pandemic H1N1. Clin Infect Dis. 2014;58(8):1095-103

PMID:24488975 DOI:10.1093/cid/ciu053

Wang C, Horby PW, Hayden FG, Gao GF. A novel coronavirus outbreak of global health concern. Lancet. 2020;395:470-3 PMID: 31986257 DOI: 10.1016/S0140-6736(20)30185-9

WHO - World Health Organization. Coronavirus disease (COVID-19) Pandemic, 2020a available at: https://www. who.int/emergencies/diseases/novel-coronavirus-2019).

WHO - World Health Organization. Laboratory testing for 2019 novel coronavirus (2019-nCoV) in suspected human cases. Interim guidance, 2020b. Avaiable at: https://www. who.int/publications-detail/laboratory-testing-for-2019-novel-coronavirus-in-suspected-human-cases-20200117

Wu F, Zhao S, Yu B, Chen YM, Wang W, Song ZG, Hu Y, Tao ZW, Tian JH, Pei YY, Yuan ML, Zhang YL, Dai FH, Liu Y, Wang QM, Zheng JJ, Xu L, Holmes EC, Zhang YZ. A new coronavirus associated with human respiratory disease in China. Nature. 2020; 579:265-9.

PMID: 32015508 DOI: $10.1038 / s 41586-020-2008-3$

Wu Z, McGoogan JM. Characteristics of and Important Lessons from the Coronavirus Disease 2019 (COVID-19) Outbreak in China: Summary of a Report of 72314 Cases from the Chinese Center for Disease Control and Prevention. JAMA. 2020

PMID: 32091533 DOI:10.1001/jama.2020.2648

Xiao SY, Wu Y, Liu H. Evolving status of the 2019 novel coronavirus infection: Proposal of conventional serologic assays for disease diagnosis and infection monitoring. J Med Virol. 2020;92:464-7 PMID: 32031264. DOI: $10.1002 / j m v .25702$

Xu X, Han MS, Mirkin CA. A Gold-Nanoparticle-Based Real-Time Colorimetric Screening Method for Endonuclease Activity and Inhibition. Angew Chem Int Ed Engl. 2007; 46:3468-70 PMID:17385814 DOI:10.1002/anie.200605249

Yalow RS, Berson SA. Immunoassay of endogenous plasma insulin in man. Obes Res. 1996; 4:583-600. PMID: 8946445 DOI:10.1002/j.1550-8528.1996.tb00274.x 
Zhou G, Mao X, Juncker D. Immunochromatographic assay on thread. Anal. Chem. 2012, 84:7736-43

PMID: 22889381 DOI: $10.1021 /$ ac301082d
Zou L, Ruan F, Huang M, Liang L, Huang H, Hong Z, Yu J, Kang $M$, Song $Y$, Xia J, Guo Q, Song T, He J, Yen HL, Peiris M, Wu J. SARS-CoV-2 Viral Load in Upper Respiratory Specimens of Infected Patients. N Engl J Med. 2020;382:11779. PMID: 32074444 DOI: 10.1056/NEJMc2001737 